\title{
CERATOACANTOMA DE LÁBIO INFERIOR EM PACIENTE IMUNOSSUPRIMIDO - UM RELATO DE CASO
}

Adriano KUCZYNSKI, Joslei Carlos BOHN, Cassiano Lima CHAIBEN, Francisca Berenice GIL, Antonio Adilson Soares de LIMA

O ceratoacantoma (CE) é uma lesão arredondada de crescimento rápido e resolução espontânea. As lesões podem ser múltiplas, disseminadas e associadas com algumas síndromes. Sua etiologia é desconhecida, mas é observada com frequência em pacientes expostos ao sol. $\mathrm{O}$ objetivo deste trabalho é relatar um caso de CE em lábio inferior de um paciente imunossuprimido. Homem de 40 anos procurou o Hospital Oswaldo Cruz com sintomas de tosse, fraqueza, perda de peso, astenia e diarréia. A história médica refere infecção pelo HIV. O exame físico revelou uma lesão arredondada com bordas elevadas, endurecidas, coberta por uma crosta acastanhada no vermelhão do lábio inferior e com evolução de três meses. Uma biópsia excisional com margem de segurança foi executada. $O$ diagnóstico de $\mathrm{CE}$ foi estabelecido pela histopatologia que revelou fragmento de lesão exibindo intensa proliferação epitelial, hiperceratose, cristas epiteliais alongadas, disceratose, hipercromatismo nuclear e a membrana basal íntegra. Não houve recidivas após acompanhamento por seis meses. O CE é uma lesão com características próprias, que pode se assemelhar com as do carcinoma espinocelular. Neste contexto, 0 estudo das características histopatológicas continua sendo o recurso mais recomendado para diagnóstico, especialmente nos casos em que a remoção cirúrgica é importante por razões estéticas.

Palavras chave: Mucosa bucal; Ceratoacantoma; Proliferação Celular; Anormalidades da Boca. 